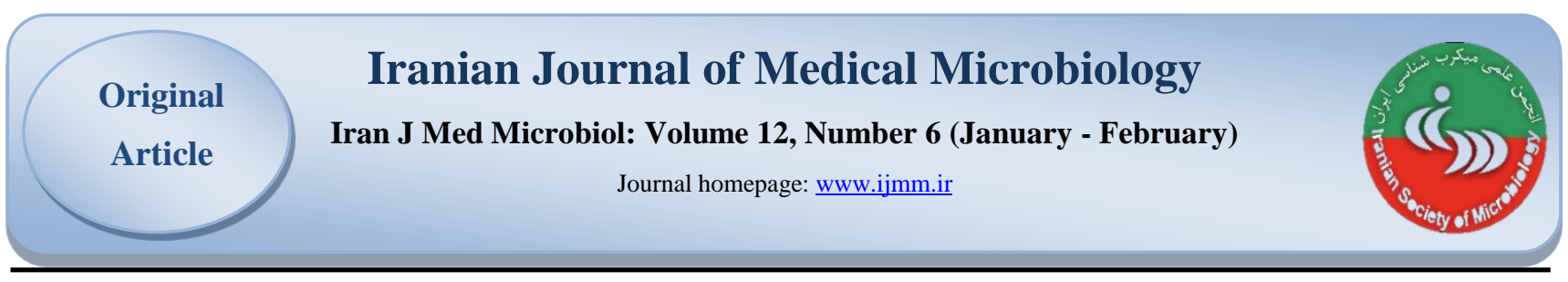

\title{
Synergistic Antifungal Effects of Lactobacillus Strains and Nano Selenium on Growth Inhibition of Candida albicans
}

\author{
Sadegh Cheraghi Saray ${ }^{1}$, Ali Hosseinkhani ${ }^{\text {* }}$, Akbar Taghizadeh ${ }^{1}$ \\ Hamid Mohammadzadeh ${ }^{1}$, Hamed Hamishehkar ${ }^{2}$
}

1. Department of Animal Science, University of Tabriz, Tabriz, Iran

2. Drug Applied Research Center, Tabriz University of Medical Sciences, Tabriz, Iran

\section{Article Information}

\section{Article history:}

Received: 2018/11/08

Accepted: 2019/01/17

Available online: 2019/03/06

\section{Article Subject:}

Medical Mycology

IJMM 2019; 12(6): 432-441

Corresponding author:

\section{Ali Hosseinkhani}

Department of Animal

Science, University of Tabriz,

Tabriz, Iran

\section{Email:}

hosseinkhani2000@yahoo.com

Use your device to scan and read the article online

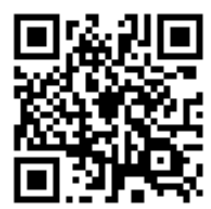

\section{Abstract}

Background and Aims: Candidiasis is a fungal infection caused by Candida albicans. Uncontrolled use of antibiotics has resulted in drug resistance. This study has been conducted to find a suitable alternative for these drugs.

Materials and Methods: Primarily, standard and clinical isolates of C.albicans were collected. In order to indentify clinical isolates from lambs, the conventional mycological methods CHROM candida agar and germ tube production were used. The Antifungal effects of experimental treatments were evaluated against C.albicans by disk diffusion and measuring the growth inhibition zone in well diffusion method. Moreover, the MIC and MFC of experimental treatments were determined by microdilution method.

Results: The results of the well and disk diffusion methods showed that in both tests, the highest growth inhibition zone of the "Nano selenium-loaded lactobacillus" treatment was 29/41 and $27.64 \mathrm{~mm}$, respectively on the standard strain of C.albicans. The results of MIC and MFC determination showed that in all experimental periods, "Nano selenium-loaded lactobacillus" and "Nano selenium+Lactobacillus" treatments with 473.80 and $511.91 \mu \mathrm{g} / \mathrm{ml}$ for MIC and 807.66 and $845.28 \mu \mathrm{g} / \mathrm{ml}$ for MFC had the lowest amounts compared to other treatments $(P<0.05)$.

Conclusions: The results of microbial tests on C.albicans confirm the antifungal ability of "Nano selenium-loaded lactobacillus" treatment. Therefore, provided that this test is repeated in future studies and the accuracy of these results is ensured, manufacturing of this product or industrial supplements with this formulation may be advised for prevention or treatment of fungal infections.

Keywords: Candida albicans, Nano selenium, Lactobacillus, Lamb,Resistance, Antifungal

\footnotetext{
Copyrights @ 2019, Iran J Med Microbiol This is an open-access article distributed under the terms of the Creative Commons Attribution-noncommercial 4.0 International
} License which permits copy and redistribute the material just in noncommercial usages, provided the original work is properly cite.

How to cite this article:

Cheraghi Saray S, Hosseinkhani A, Taghizadeh A, Mohammadzadeh H, Hamishekar H. Synergistic Antifungal Effects of Lactobacillus Strains and Nano Selenium on Growth Inhibition of Candida albicans. Iran J Med Microbiol. 2019; 12 (6) :432-441 


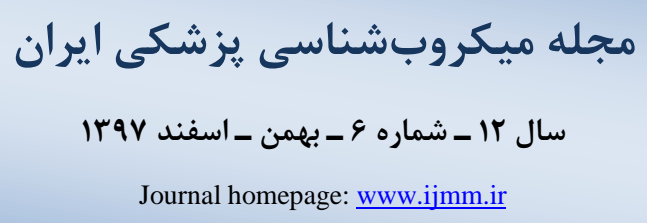

\section{اثرات خدقارجى و همافزايى برخى كونهاى لاكتوباسيل و نانوذرات سلنيوم بر مهار رشد كانديدا آلبكنس}

صادق جراغىسراى'، على حسين خانى *'، اكبر تقىزاده'، حميد محمدزاده'، حامد هميشه كار؟

$$
\begin{aligned}
& \text { ا. ا. كروه علوم دامى، دانشكده كشاورزى، دانشعاه تبريز، تبريز، ايران }
\end{aligned}
$$

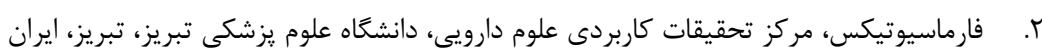

\section{جكيله}

زمينه و هدف: كانديديازيس عفونت قارجى است كه عامل اصلى آن كانديدا آلبيكنس است. استفاده بىرويه از

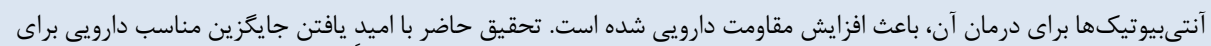
اين عفونت انجام كرفت. مواد و روش كار: در وهلئ اول، كونههاى استاندارد و بالينى كانديدا آلبيكنس جمعآورى شده و بهمنظور تشخيص جدايههاى

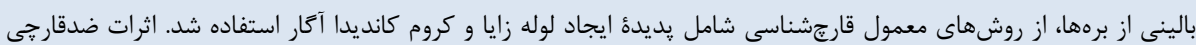

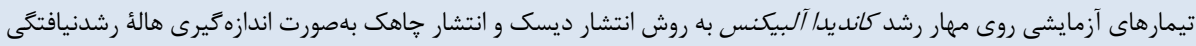

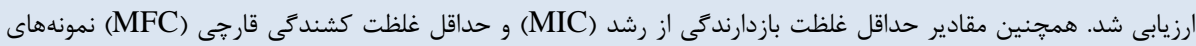

$$
\text { آزمايشى به روش رقتسازى تعيين شد. }
$$

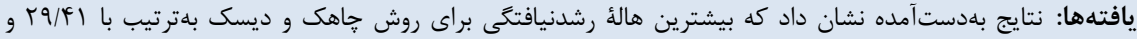

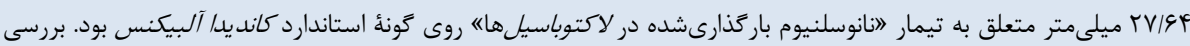

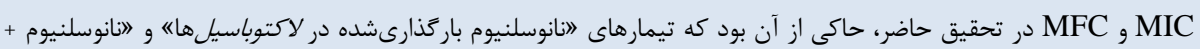

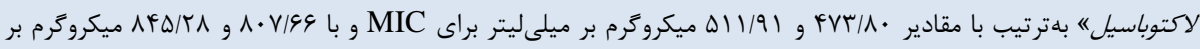

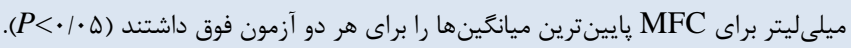

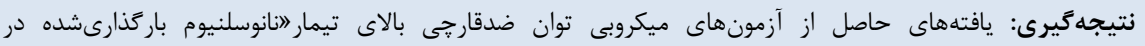

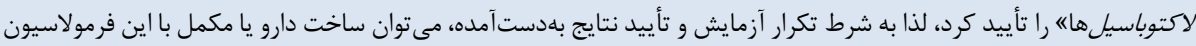

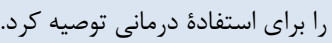
كلمات كليدى: كانديدا آلبيكنس، نانوسلنيوم، لاكتوباسيلوس، بره، مقاومت، ضدقارجى
اطلاعات مقاله

تاريخجُه مقاله

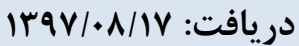

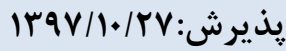

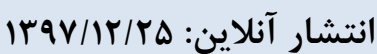

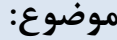

قارج شناسى بزشكى :

IJMM1397;12(6): 432-441

نويسندهُ مسئول:

على حسين خانى

گروه علوم دامى، دانشكده كشاورزى،

دانشعاه تبريز، تبريز، ايران

بست الكترونيك:

hosseinkhani2000@yahoo.com
نيز قادرند در شرايطى كه دفاع بدن (Candida dubliniensis)

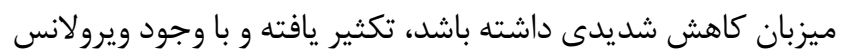

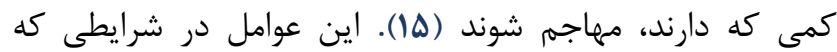
مقاومت ميزبان بهصورت موضعى يا سيستميك بهصورت اوليه و يا

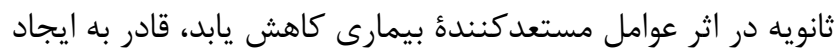
بيمارى در هر ناحيه از بدن خواهند بود (ه). رويئ معمول براى ييشگيرى از اين عفونتها، استفاده از داروهاى مختلف گروه آزول
كانديديازيس از جمله شايعترين بيمارىهاى قارجى است كه در سالهاى اخير گسترش جشمخيرى داشته است. عامل بيمارى، قارجى فرصتطلب از جنس كانديدا است كه بهصورت همزيست در دستخاه گوارش، مخاطات و سطح يوست وجود دارد (ه). مهلمترين

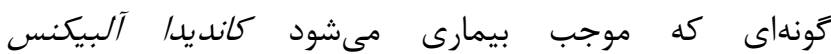
نام دارد. ساير گونههاى جنس كانديدا بلويزه (Candida albicans) تروييكاليس (Candida tropicalis) ابلينينسيس 
تراكم لاكتوباسيلى Cfu/g ^•1 و ميانگين غلظت نانوسلنيوم

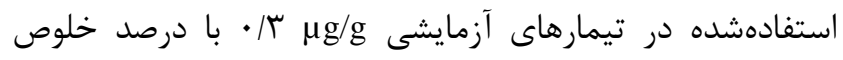
99/9

\section{تهيئ منبع سلنيومى و كونههاى لاكتوباسيلى}

نانوسلنيوم سنتزشده در شركت نانو مواد ايرانيان (مشهر،

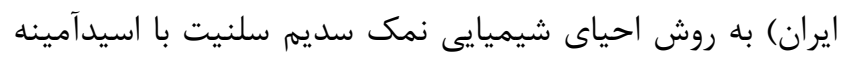

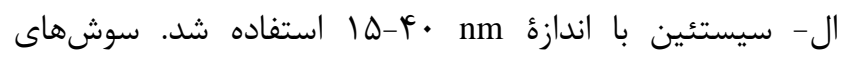

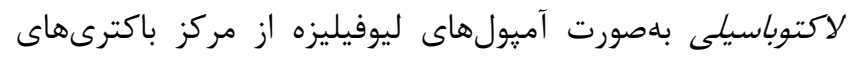

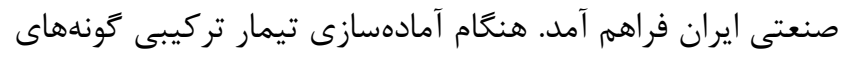

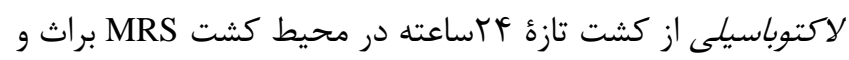

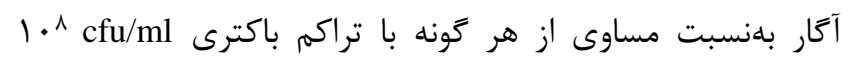

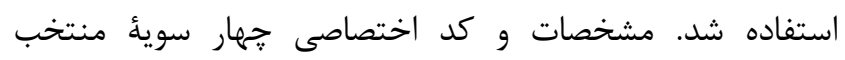
لاكتوباسيلى به شرح ذيل است:

Lactobacillus casei subsp 1608 (39392) ATCC, Lactobacillus plantarum 1058 (8014) ATCC, Lactobacillus acidophilus 1643 (20079) DSM, Lactobacillus reuteri 1655 (20016) DSM.

\section{تهيئ كونهُ استاندارد و بالينى كانديدا آلبيكنس}

نمونة استاندارد كانديدا آلبيكنس (ATCC10231) بهصورت

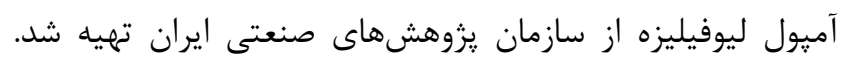

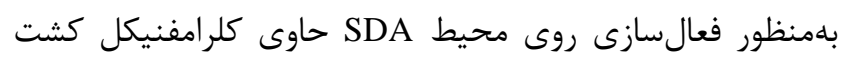

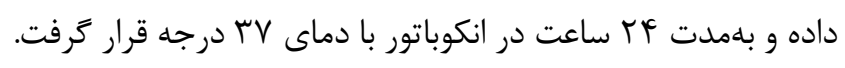

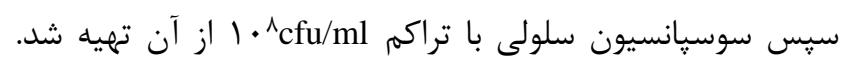

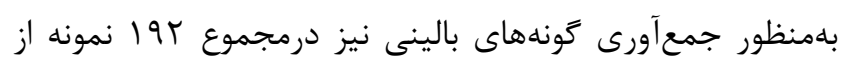

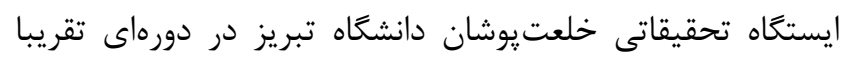

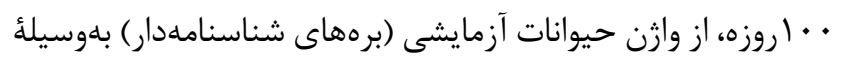

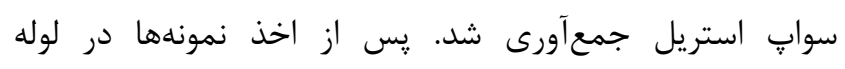

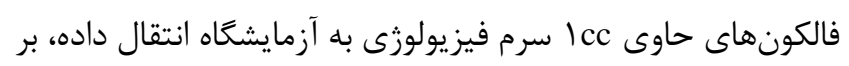

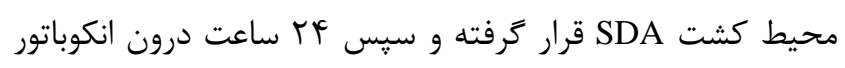

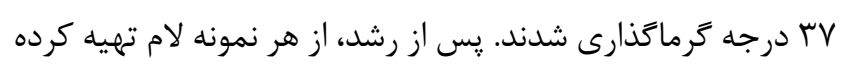

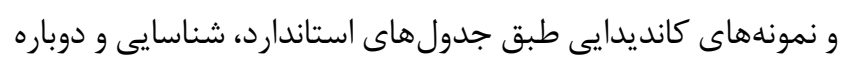

كشت داده شدند (r) - (I).

\section{بار كذارى نانوسلنيوم در تودهُ باكترىهاى لاكتوباسيلى}

طبق روش بيشنهادى Stabnikova و همكاران (1) كونهاى

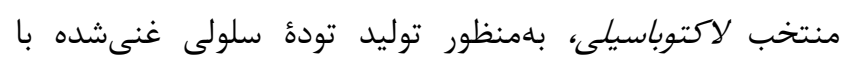

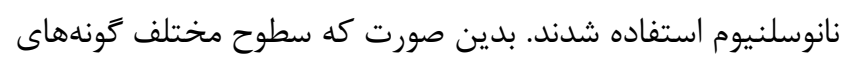

نظير فلوكونازول و ايتراكونازول است؛ اما بررسىهاى مختلف

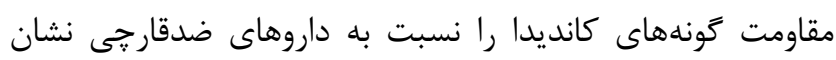

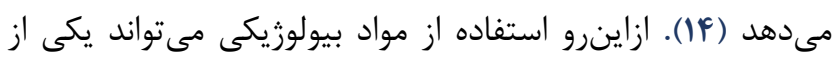

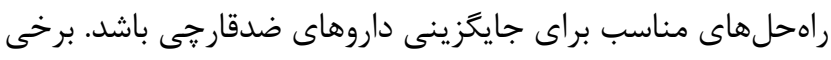

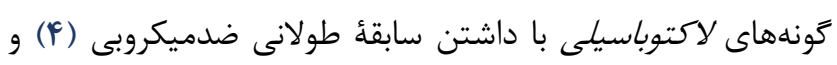

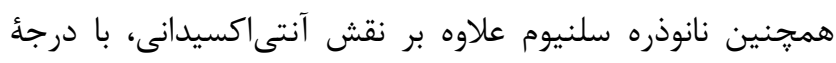
تأثيريذيرى بيشترى نسبت به شكل معمول عنصر سلنيوم، بهوسيلئ

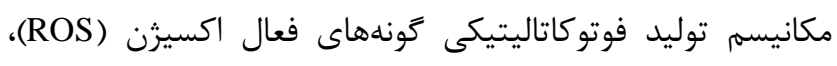

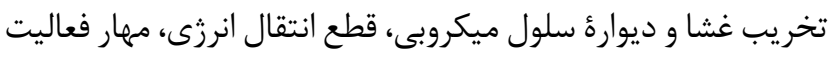

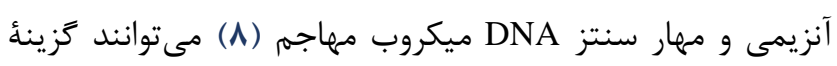

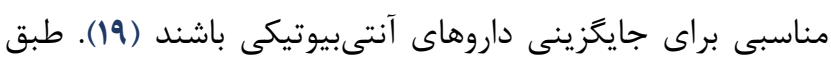

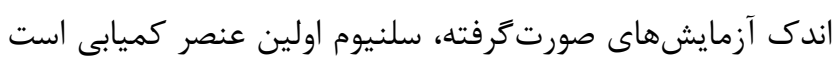

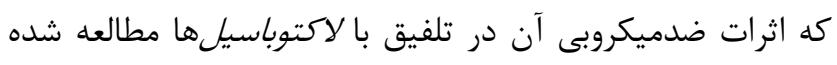

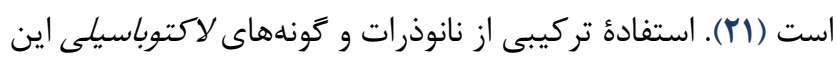

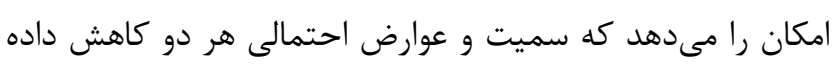

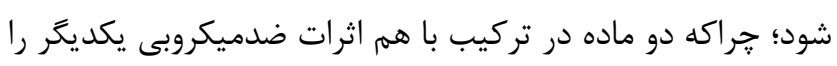

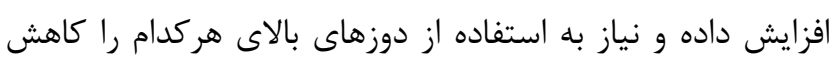

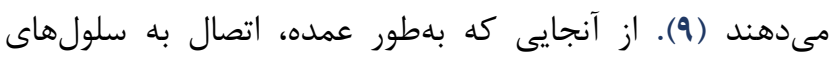

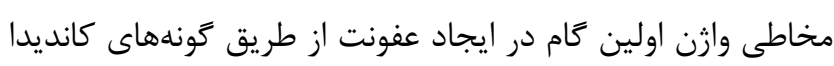

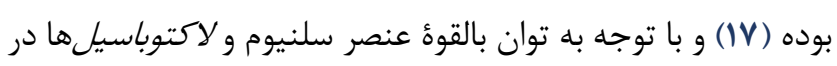

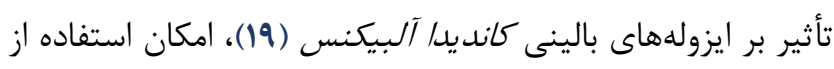

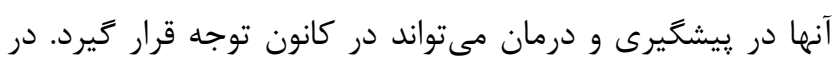

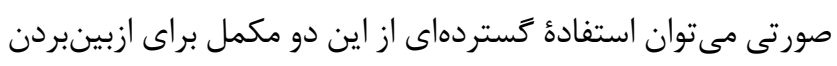

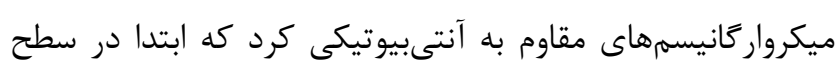

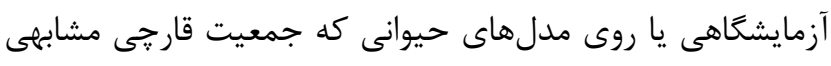

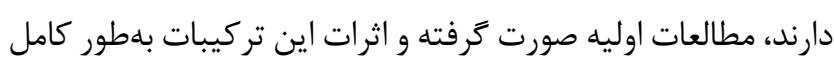

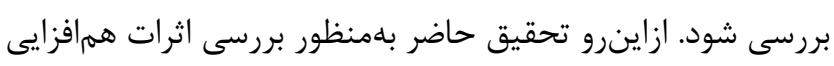

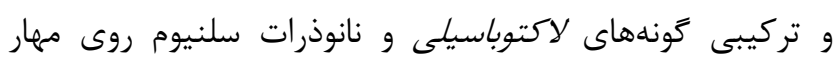

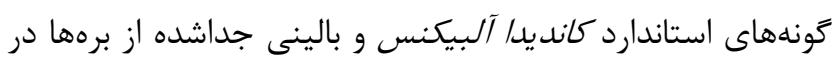
سطح آزمايشَاهى انجام ترفت.

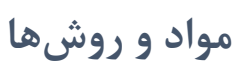
كروههاى آزمايشى

تحقيق حاضر يك مطالعؤ تجربى بود كه اجراى تمامى مراحل

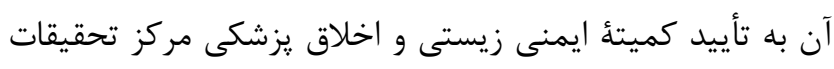

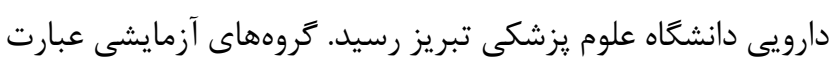

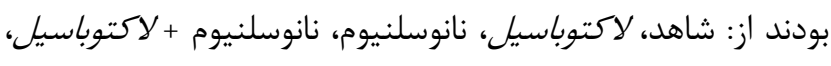

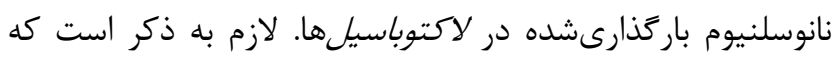


تعيين اثر ضد قارجى تيمارهاى آزمايشى به روش

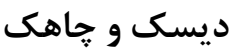

در اين يزوهش از محيط كشت SDA محتوى كلرامفنيكل

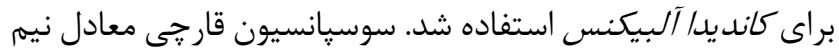
مك فارلند تهيه و بهوسيلهُ سواب استريل روى لايهٔ سطحى محيط

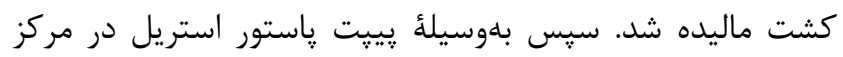

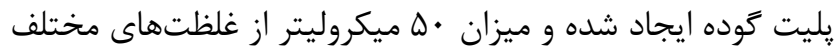

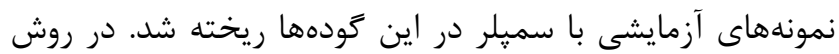

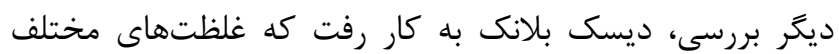

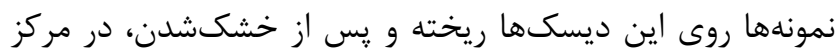
يليتهاى كشتدادهشده قرار كرفت. درنهايت يليتها به انكوباتور

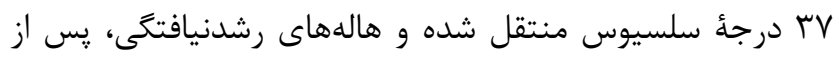
طىشدن زمان رشد قارج بررسى شدند.

تعيين حداقل غلظت مهار رشد (MIC) و حداقل غلظت كشندكى قارجى (MFC)

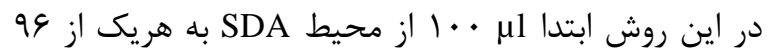

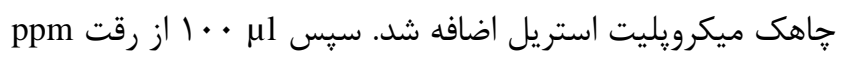

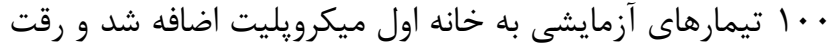

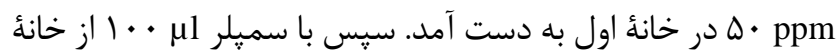

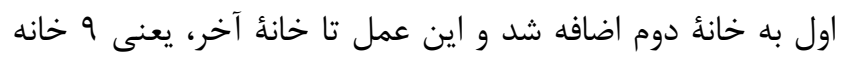

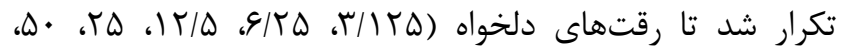

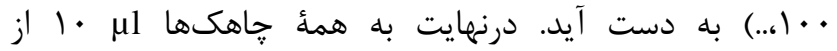
سوسيانسيون قارجى مربوط به هر ايزوله اضافه شد. ميكرويليتها

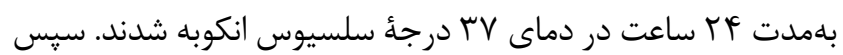
رشد كلنى قارجها بررسى و MIC و MFC نمونههاى آزمايشى تعيين

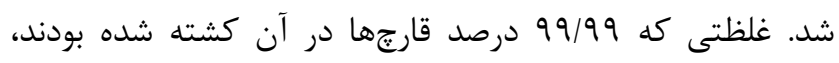
بهنوان MFC و خاهك شفاف بهعنوان MIC انتخاب شد.

$$
\text { بررسى آمارى }
$$

آناليز آمارى با نرمافزار SAS صورت كرفت و مقايسٔ

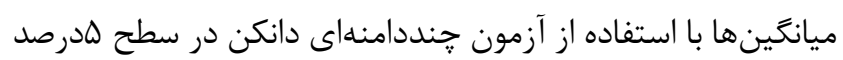

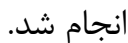

\section{بافتهها}

تصوير بهدستآمده از ميكروسكوٍ الكترونى روبشى نانوذرات

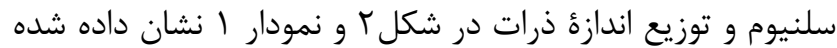

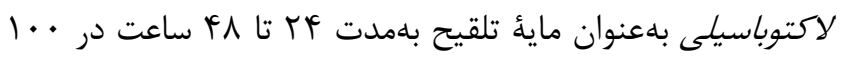

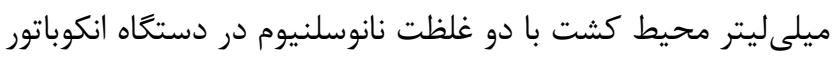
شيكردار كشت داده شدند. محيط كشت پايه، ملاس نيشكر استريل

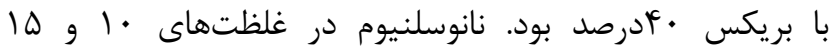
ميكروكرم بر ميلىليتر در زمانهاى مشخص به محيط كشت اضافه

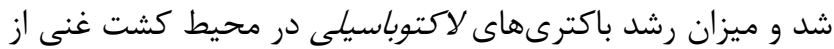

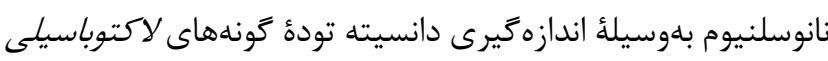

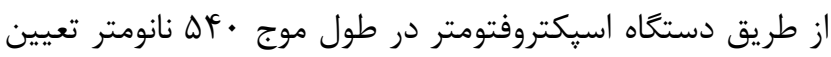

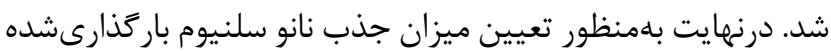
در ساختار كونههاى لاكتوباسيلى، روش جذب اتمى كورهاى به كار

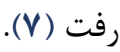

\section{تشخيص كونههاى آلبيكنس: يديدهُ ايجاد لوله زايا و كشت در محيط كروم كانديدا آتار} براى تشخيص كونههاى كانديدا آلبيكنس، يديده ايجاد لوله

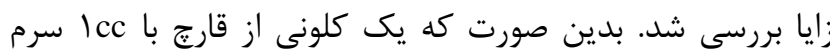

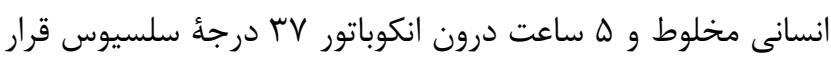
داده شد. يس از كذشت زمان تعيينشده، مقدارى از سوسيانسيون

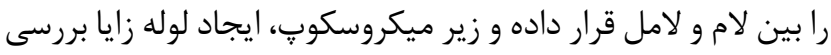

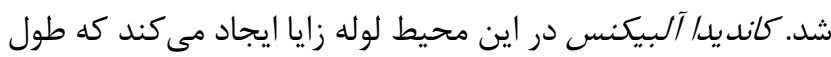

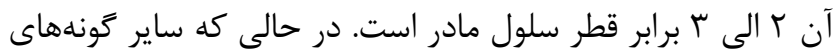
كانديدا، لوله زاياى بسيار كوتاهى داشته يا اصلا لوله زايا ايجاد الياد نمى كنند. در روشى ديكر، كشت در محيط كروم آكار كانديدا انجام شد. بدين ترتيب كه يك كلونى از كشت تازء كانديدا، روى محيط ديط كروم كانديدا آكار بلهصورت خطى كشت داده و در انكوباتور با دماى

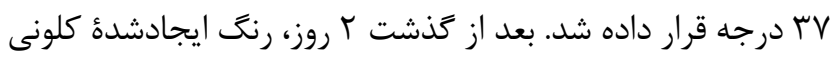

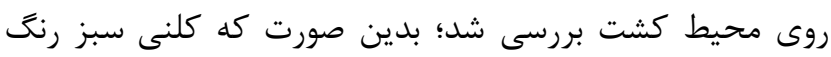

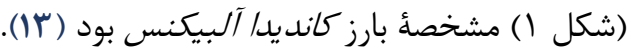

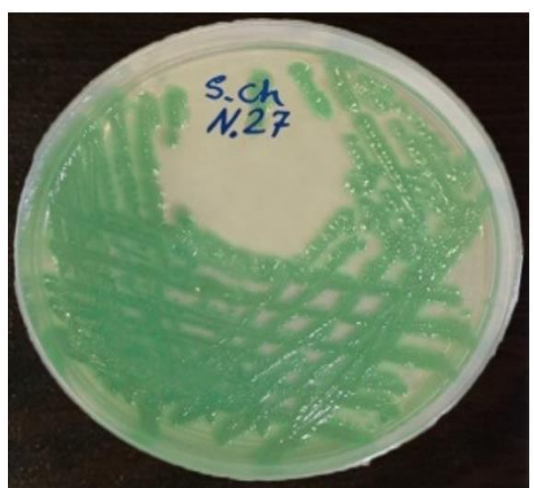

شكل ا. كلنىهاى سبز رنَّ كانديدا آلبيكنس در محيط كروم كانديدا آَار 
بازدارندگى را بهترتيب براى انتشار از خاهك و ديسك داشت.

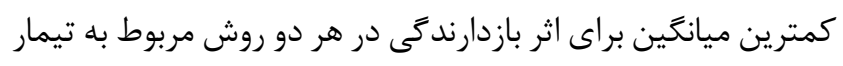

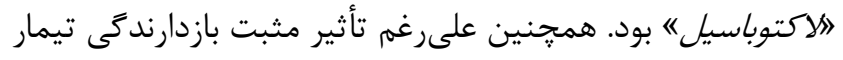

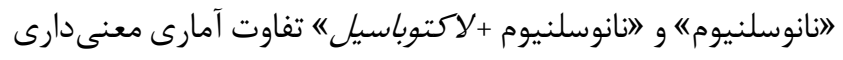

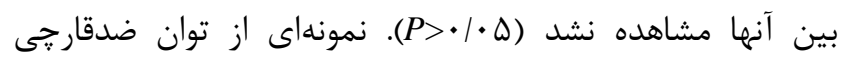

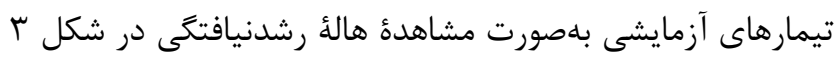
نشان داده شده است.

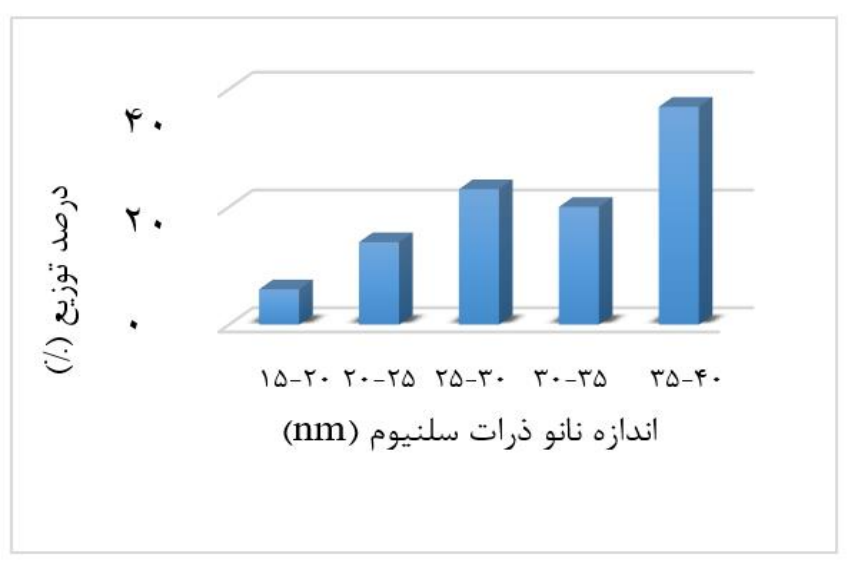

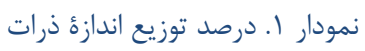

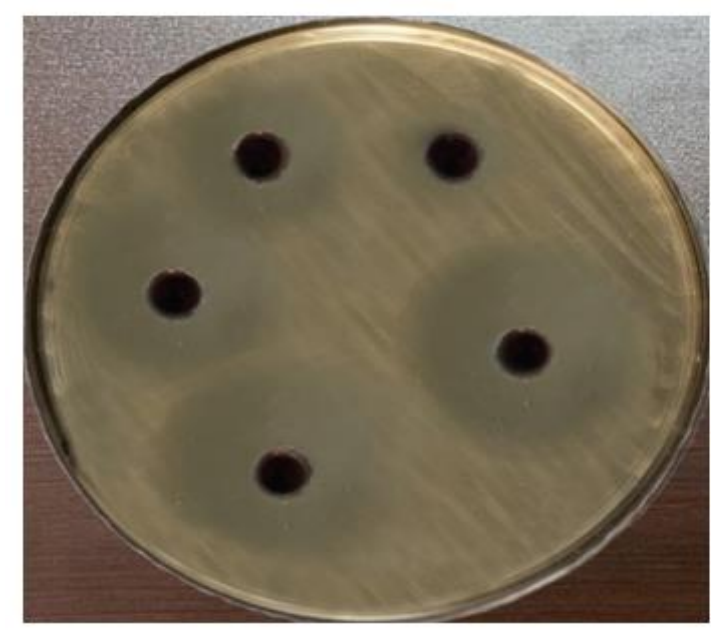

(ب)
اثر ضدقارجى تيمارهاى آزمايشى به روش انتشار

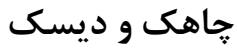

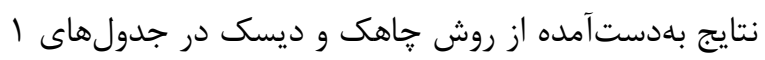

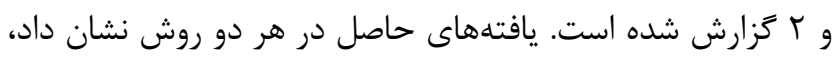

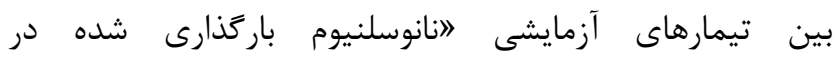

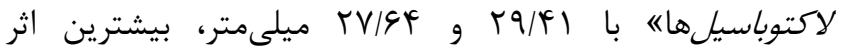

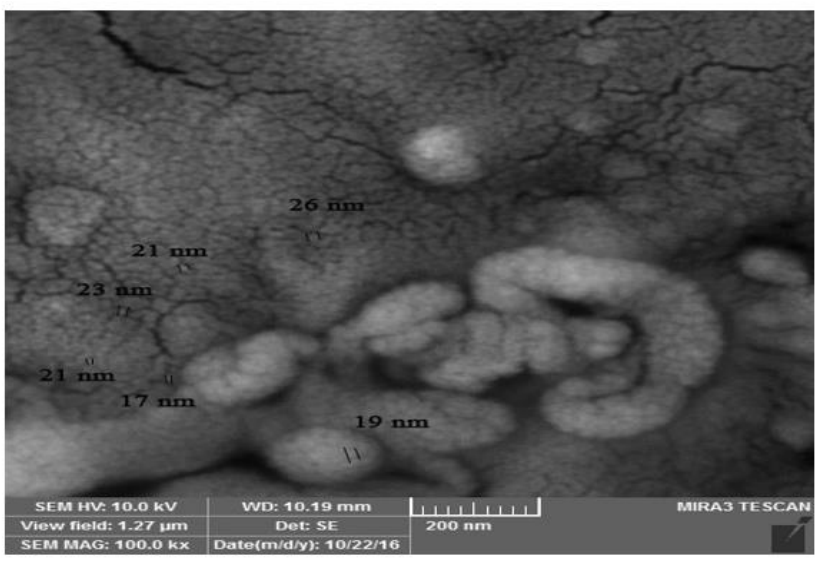

شكل r. تصوير ميكروسكوب الكترونى روبشى نانوذرات سلنيوم

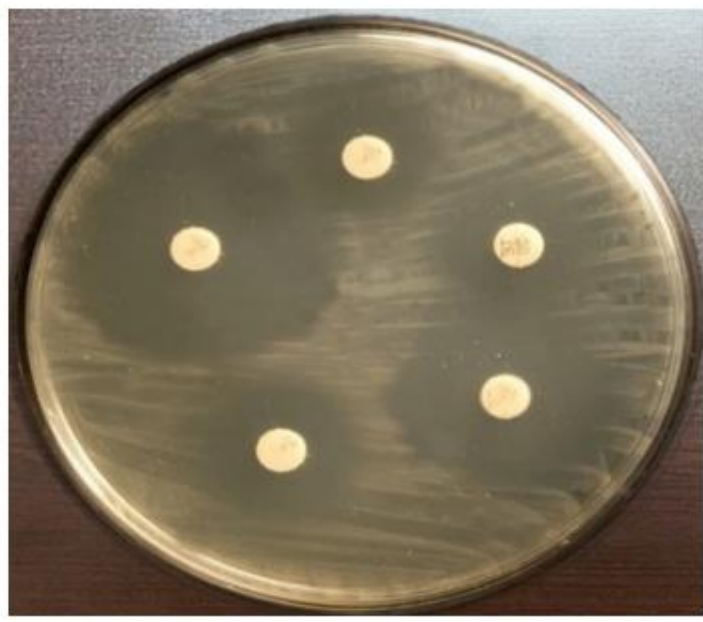

(الف)

شكل r. نمونهاى از ناحئٔ مهار رشد مخمر كانديدا آلبيكنس از طريق تيمارهاى آزمايشى: الف (روش ديسك) ب (روش جاهك) 


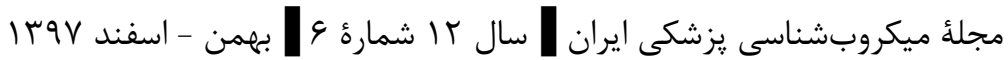

جدول (. خاصيت ضدقارجى تيمارهاى آزمايشى به روش انتشار از خاهك (برحسب ميلىمتر)

\begin{tabular}{|c|c|c|c|c|c|c|c|c|}
\hline ميانغين & & آزمايش سوم & & كايش دوم & & ل & آزماي & \\
\hline $\begin{array}{l}\text { C.albicans- } \\
\text { Clinical }\end{array}$ & $\begin{array}{l}\text { C.albicans- } \\
\text { Standard }\end{array}$ & $\begin{array}{l}\text { C.albicans- } \\
\text { Clinical }\end{array}$ & $\begin{array}{l}\text { C.albicans- } \\
\text { Standard }\end{array}$ & $\begin{array}{l}\text { C.albicans- } \\
\text { Clinical }\end{array}$ & $\begin{array}{l}\text { C.albicans- } \\
\text { Standard }\end{array}$ & $\begin{array}{l}\text { C.albicans- } \\
\text { Clinical }\end{array}$ & $\begin{array}{l}\text { C.albicans- } \\
\text { Standard }\end{array}$ & \\
\hline - & - & - & - & - & - & - & - & شاهد \\
\hline $\mid r / F T \pm \| \cdot \Delta^{c}$ & $\mid q / r q \pm 1 / \cdot r^{c}$ & $1 \cdot / V T$ & $|\Delta / \Gamma|$ & $\mid r / T \Delta$ & $11 / \cdot 9$ & $|V / T|$ & $10 / V$. & لاكتوباسيلها \\
\hline$r \cdot / \uparrow \wedge \pm 1 / r \Lambda^{b}$ & $r r / q \cdot \pm 1 / T r^{b}$ & IV/GY & $r T / \cdot V$ & TI/VT & $r r / l \varphi$ & $r T / l$. & rI/qF & نانوسلنيوم \\
\hline$T r / r \Lambda \pm 1 / \Delta T^{b}$ & $r r / \Delta \cdot \pm 1 / F q b$ & $r \cdot / 19$ & $t r / l$. & $r r / r$. & $r \cdot 191$ & TH/VG & $r V / F q$ & لانانوسلنيوم + \\
\hline$r V / r \Delta \pm 1 / \Delta \Delta^{\mathrm{a}}$ & $\langle q / 4| \pm 1 / \Delta \Lambda^{a}$ & rब/19 & $r \Lambda / r \Delta$ & $r G / D F$ & TN/AT & $r q / \cdot V$ & $r \mid / l q$ & باركذارىشدانوهيوم در \\
\hline
\end{tabular}

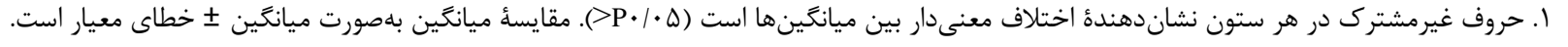

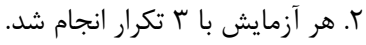

جدول r. خاصيت ضد قارجى تيمارهاى آزمايشى به روش انتشار از ديسك (برحسب ميلىمتر)

\begin{tabular}{|c|c|c|c|c|c|c|c|c|}
\hline ميانگين & & آزمايش سوم & & ايش دوم & & ل & آزماي & \\
\hline $\begin{array}{l}\text { C.albicans- } \\
\text { Clinical }\end{array}$ & $\begin{array}{l}\text { C.albicans- } \\
\text { Standard }\end{array}$ & $\begin{array}{l}\text { C.albicans- } \\
\text { Clinical }\end{array}$ & $\begin{array}{l}\text { C.albicans- } \\
\text { Standard }\end{array}$ & $\begin{array}{l}\text { C.albicans- } \\
\text { Clinical }\end{array}$ & $\begin{array}{l}\text { C.albicans- } \\
\text { Standard }\end{array}$ & $\begin{array}{l}\text { C.albicans- } \\
\text { Clinical }\end{array}$ & $\begin{array}{l}\text { C.albicans- } \\
\text { Standard }\end{array}$ & \\
\hline - & - & - & - & - & - & - & - & شاهد \\
\hline$\| / / \Lambda \pm 1 / 1 \cdot c$ & $\mid \Delta / \Delta \varepsilon \pm 1 / / f^{c c}$ & १/VQ & $1 r / 90$ & $1 \cdot / r v$ & $I V / T$. & $|F| \cdot r$ & $1 Q / V F$ & لاكتوباسيلها \\
\hline $1 N / T F \pm 1 / T F^{\prime}$ & $r \cdot \mid \xi \wedge \pm 1 / \mu^{r b}$ & $\mid f / T V$ & $r / / r$. & $19 / .4$ & $r 1 / 90$ & $r \mid / r$. & $11 / 9$. & نانوسلنيوم \\
\hline $\mid N / \Delta f \pm 1 / \Gamma \cdot b$ & $r r / \Delta \cdot \pm \mid / \Delta)^{b}$ & $10 / \lambda$. & $r \cdot \mid \Lambda \Lambda$ & $1 V / 99$ & $T M / T F$ & $Y T / T V$ & TQ/TS & لانوسلنوباسيل+ \\
\hline$r F / V T \pm 1 / r F^{a}$ & $r V / \varepsilon q \pm 1 / \varepsilon \cdot a$ & Tr/qT & $r \Delta / \varepsilon \wedge$ & $r \Delta / r \Lambda$ & $r \Lambda / r$. & $r \Delta / \wedge \Delta$ & KN/9T & 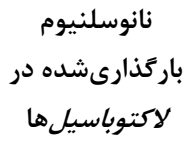 \\
\hline
\end{tabular}

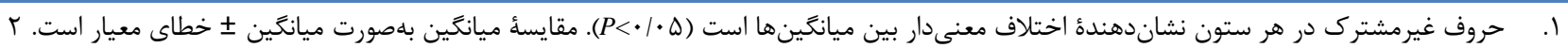

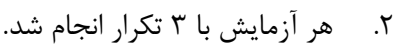

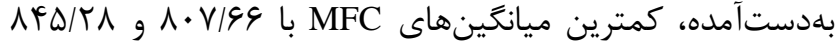
ميكروگرم بر ميلىليتر، بهترتيب مربوط به تيمارهاى الانوسلنيوم

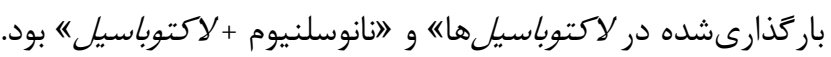
بين دو تيمار يادشده، تفاوت آمارى معنى بارارى وجود نداشت

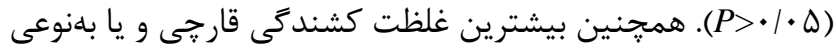

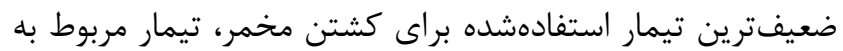

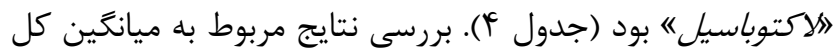
MFC وشخص كرد كه از لحاظ حساسيت بين گونههاى كانديد/ آلبيكنس آزمايششده در مقايسه با تيمارها، اختلاف

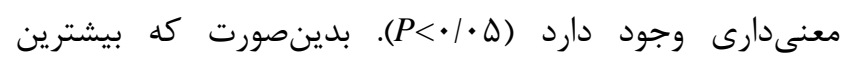
حساسيت مربوط به گونهُ استاندارد كانديدا آلبيكنس و ومترين حساسيت متعلق به گُنهُ بالينى آن بود.
اثر ضدقارجى تيمارهاى آزمايشى به روش MIC و MFC تعيين MIC نمونهها نشان داد مكملهاى آزمايششده، هم در حالت جداعانه و هم در صورت استفاده توأم، داراى فعاليت ضدقارجى هستند. بدين نحو كه تيمارهاى انانوسلنيوم باركذارىشده در لاكتوباسيلها《 و 》انانوسلنيوم + لاكتوباسيل

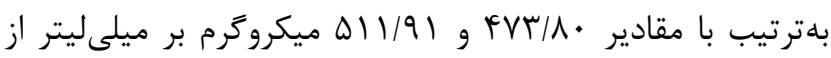
ميانگين MIC پايينترى نسبت به ساير تيمارها برخوردار بودند كه نشاندهنده قدرت زياد اين مكملها در جلوگيرى از رشد ياتوزنهاى كانديدا آلبيكنس بود و تفاوت معنى دارى از اين لحاظ با ردها

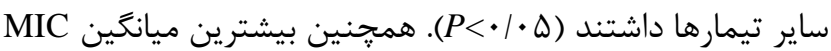
مربوط به تيمار "اكتوباسيل" بود (جدول "). طبق نتايج 
جدول r. ميزان حداقل غلظت مهارى (MIC) تيمارهاى آزمايشى برعليه گَونهاى كانديدا آلبيكنس (برحسب ميكروگرم بر ميلىليتر)

\begin{tabular}{|c|c|c|c|c|c|c|c|c|}
\hline \multicolumn{2}{|c|}{ ميانكَين } & \multicolumn{2}{|c|}{ آزمايش سوم } & \multicolumn{2}{|c|}{ آزمايش دوم } & \multicolumn{2}{|c|}{ آزمايش اول } & \\
\hline $\begin{array}{l}\text { C.albicans- } \\
\text { Clinical }\end{array}$ & $\begin{array}{l}\text { C.albicans- } \\
\text { Standard }\end{array}$ & $\begin{array}{l}\text { C.albicans- } \\
\text { Clinical }\end{array}$ & $\begin{array}{l}\text { C.albicans- } \\
\text { Standard }\end{array}$ & $\begin{array}{l}\text { C.albicans- } \\
\text { Clinical }\end{array}$ & $\begin{array}{l}\text { C.albicans- } \\
\text { Standard }\end{array}$ & $\begin{array}{l}\text { C.albicans- } \\
\text { Clinical }\end{array}$ & $\begin{array}{l}\text { C.albicans- } \\
\text { Standard }\end{array}$ & \\
\hline- & - & - & - & - & - & - & - & شاهد \\
\hline$\Lambda G r / G Y \pm r N \mid q^{a}$ & $V \Delta F / T Y \pm T r / F q^{a}$ & १९५/VF & $V V Y / T \Lambda$ & NDN/GY & $999 / 19$ & VTN/D. & $V \wedge 9 / \Delta V$ & لاكتوباسيلها \\
\hline$V T \Lambda / r \cdot \pm T r / l Q^{b}$ & $4 \& r / 4 V \pm r \cdot / 11^{b}$ & $\Lambda \& 4 / D \mid$ & GAV/F. & $V \backslash N / r$. & $\Delta 91 / 91$ & $G \cdot r / I V$ & GFNFT & نانوسلنيوم \\
\hline 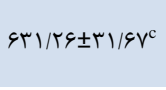 & $\Delta 11 / 9 \cdot \pm r V / V \Lambda^{c}$ & $v \cdot 9 / 19$ & $\Delta F E / I T$ & GTr/Tq & $\Delta T \cdot / F V$ & $\Delta S \& / T$ & $4 \notin 9 / 11$ & لانوسلنيوم + لانوبل+ \\
\hline$\Delta \Lambda \Lambda / F \Lambda \pm r V / q \mathcal{F}^{\mathrm{C}}$ & $F V Y / \Lambda \cdot \pm r G / r \Delta^{c}$ & $s V T / T \Delta$ & DTF/QG & $\Delta 9 \Delta / \wedge)$ & req/Ar & †৭९/4 & Frg|g| & باركنارئوسلنيوم در \\
\hline
\end{tabular}

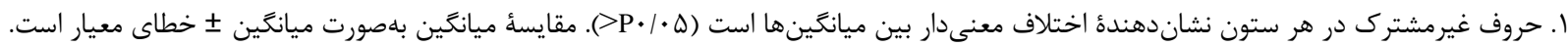
r. Mر آزمايش با ب تكرار انجام شد.

جدول f. ميزان حداقل غلظت كشندَى (MFC) تيمارهاى آزمايشى برعليه گَونهاى كانديدا آلبيكنس (برحسب ميكروگرم بر ميلىليتر)

\begin{tabular}{|c|c|c|c|c|c|c|c|c|}
\hline \multicolumn{2}{|c|}{ ميانغين } & \multicolumn{2}{|c|}{ آزمايش سوم } & \multicolumn{2}{|c|}{ آزمايش دوم } & \multicolumn{2}{|c|}{ آزمايش اول } & \\
\hline $\begin{array}{l}\text { C.albicans- } \\
\text { Clinical }\end{array}$ & $\begin{array}{l}\text { C.albicans- } \\
\text { Standard }\end{array}$ & $\begin{array}{l}\text { C.albicans- } \\
\text { Clinical }\end{array}$ & $\begin{array}{l}\text { C.albicans- } \\
\text { Standard }\end{array}$ & $\begin{array}{l}\text { C.albicans- } \\
\text { Clinical }\end{array}$ & $\begin{array}{l}\text { C.albicans- } \\
\text { Standard }\end{array}$ & $\begin{array}{l}\text { C.albicans- } \\
\text { Clinical }\end{array}$ & $\begin{array}{l}\text { C.albicans- } \\
\text { Standard }\end{array}$ & \\
\hline- & - & - & - & - & - & - & - & 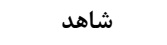 \\
\hline$|r r \varepsilon / \Delta F \pm F q / \Lambda|^{a}$ & $11 \cdot 1 / 4 q \pm \uparrow q / q \cdot a$ & $|K F N / Q|$ & $\| F F / A$. & $11 \cdot 9 / \mathrm{V}$. & $1.9 K / 4 T$ & ITYI/FT & $\| 11 V / r \Delta$ & لاكتوباسيل ها \\
\hline $111 F / \Delta T \pm F \Delta / r^{2 b}$ & $99 \% / r \Lambda \pm F \leftarrow / r \Delta^{b}$ & ITFT/DF & I. & IITN/IT & QTV/DT & $9 Y / 91$ & $1 \cdots N / T r$ & نانوسلنيوم \\
\hline$q \vee \Lambda / V \Delta \pm F F / \mathcal{F c}^{c c}$ & $\Lambda F \Delta / r \Lambda \pm F I / F q c$ & $1.95 / 90$ & $\Lambda \Lambda V / r q$ & $9 V F / 94$ & $\Lambda F r / \& \Delta$ & ^৭^/マ. & $\Lambda \cdot \Delta / 1 T$ & لانوستوباسيل+ \\
\hline$q F \& / G \cdot \pm F r / Q Y^{C}$ & $\Lambda \cdot V / \varphi q \pm F \cdot / / \Lambda^{c}$ & $1 \cdot r q / r \Delta$ & NFN/GG & १९.।AV & $111 / 9 r$ & $\Lambda F q / \Delta V$ & VAT/F. & باركتاروسلنيوم در \\
\hline
\end{tabular}

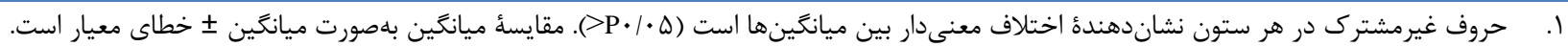

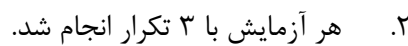

لاكتوباسيلوس /سيدوفيلوس از طريق ايجاد هالأ رشدنيافتگى مهار

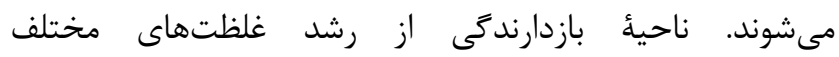

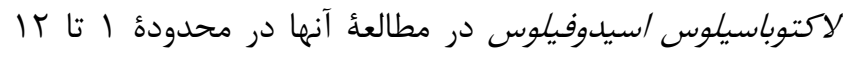

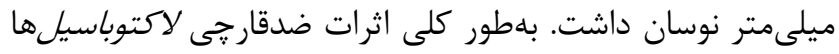
علاوه بر توليد اسيدهاى آلى (اسيد استيك و واسيد استى لاكتيك)،

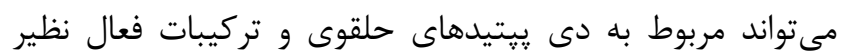

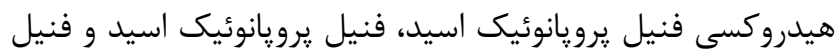
لاكتيك اسيد باشد كه در اعمال اثرات ضدميكروبى نقش زيادي فئسي

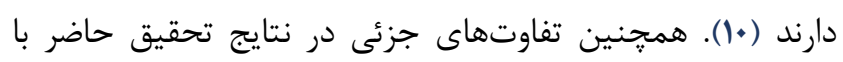

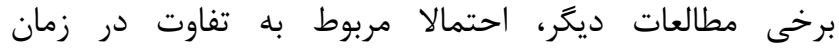

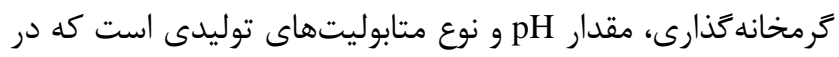

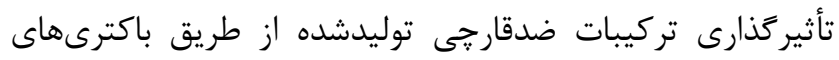

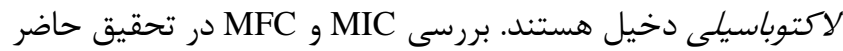

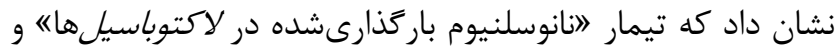

\section{بحث و نتبجه تيرى}

بررسى آزمونهاى مختلف ضدقار جى در اين تحقيق ديق حاكى از

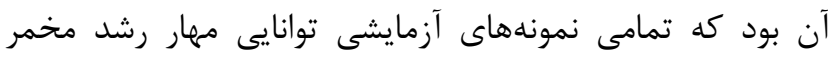

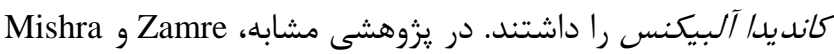

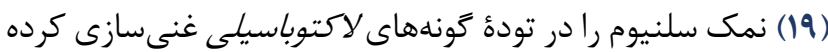
و پِ از بررسى اثرات ضدقار جى آن روى كانديدا آلبيكنس، ميانكًين

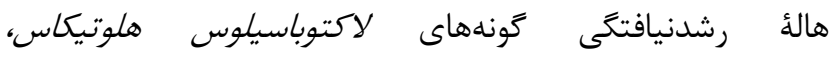

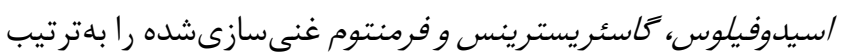

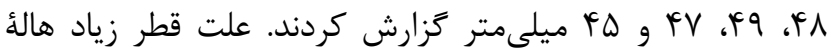
رشدنيافتكى در تحقيق آنها نسبت به مطالعُ حاضر، احتمالا مربوط

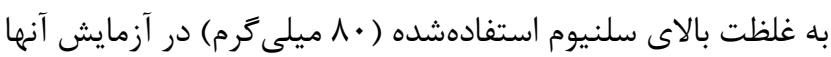

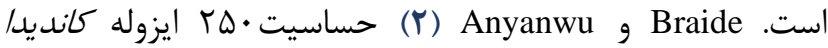
آلبيكنس را در ينج هفته نسبت به لاكتوباسيلوس /سيدوفيلوس آنساسل

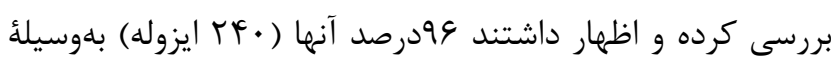


(†•) با توجه به موارد بيانشده، مىتوان نقش هريك از مكمل هاى

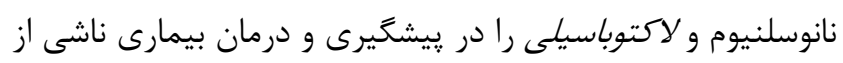

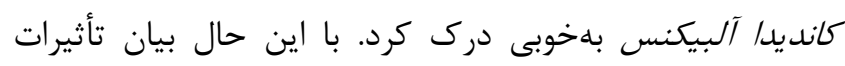

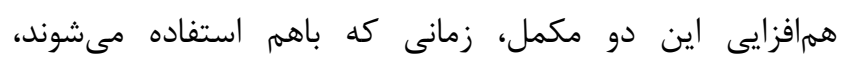

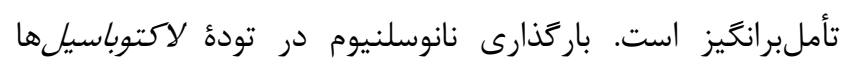

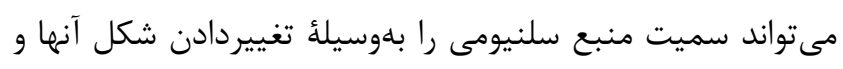

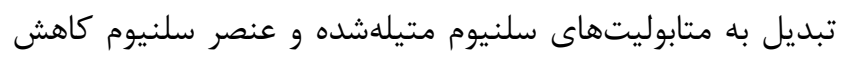

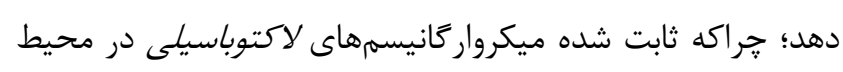

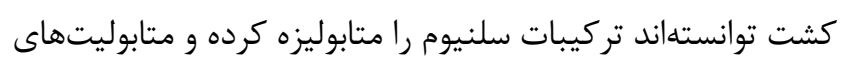
سلنيوم را از طريق متيلاسيون و دىمتيلاسيون توليد كنند (9).

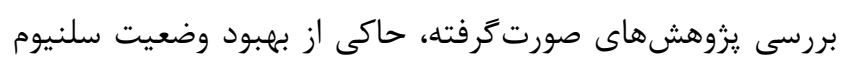

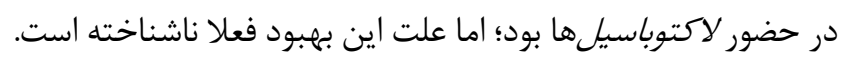

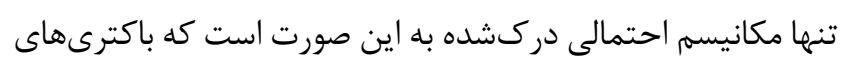

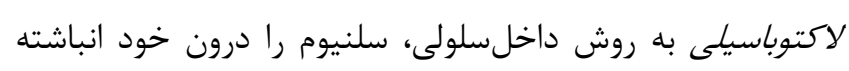

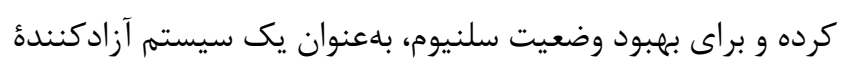

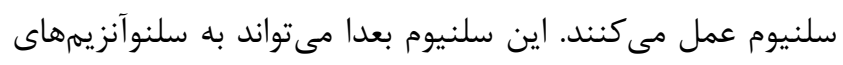

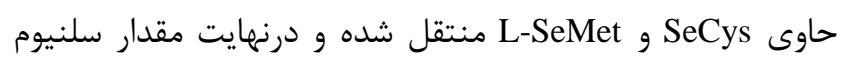

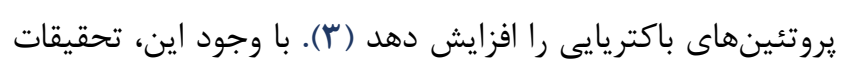

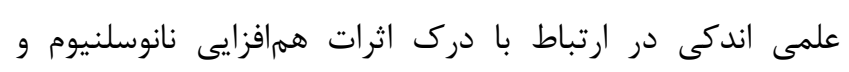

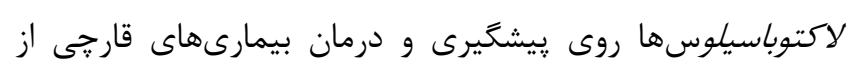

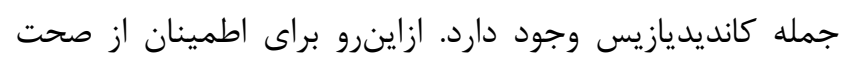

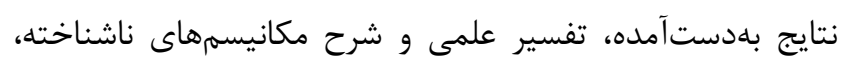
انجام مطالعات بعدى در اين زمينه توصيه مى فئرد.

بررسى اثرات ضدميكروبى نمونههاى آزمايشى نشان داد

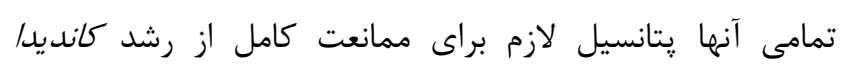

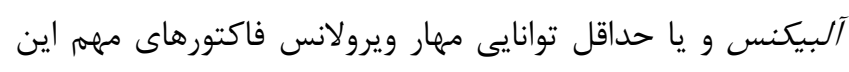

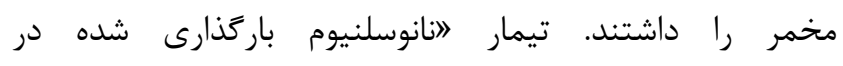

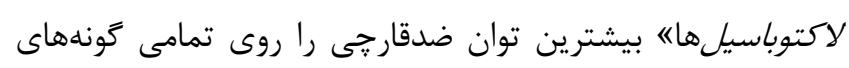

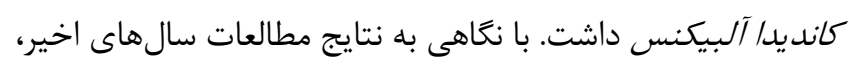

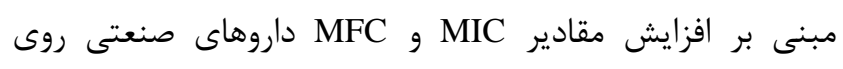

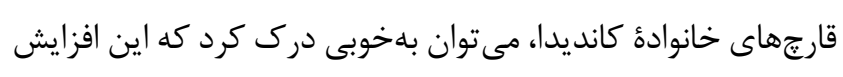

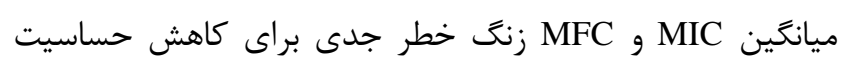

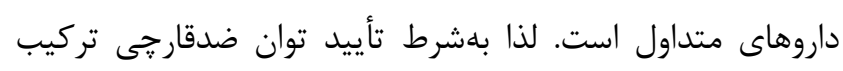

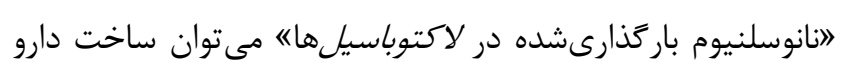

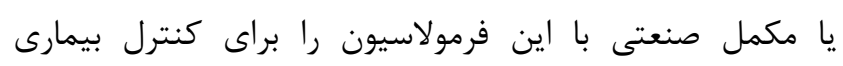
كانديديازيس توصيه كرد.
آنانوسلنيوم + لاكتوباسيلهاه پايينترين ميانكَينها را براى هر دو

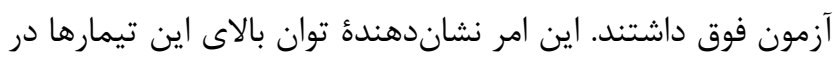

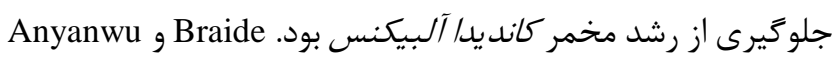

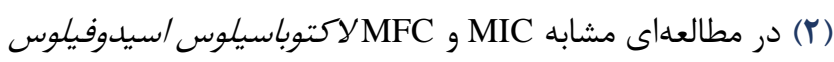

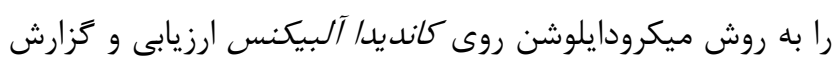

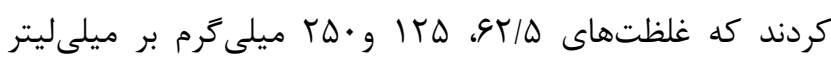

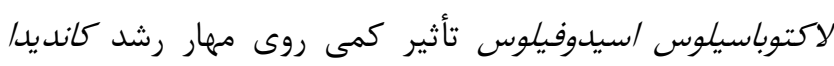

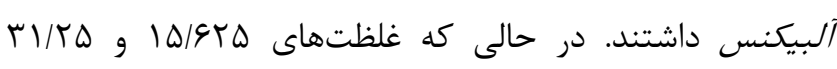

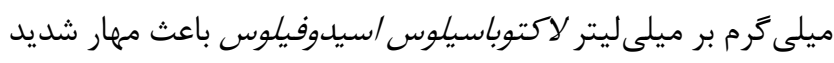

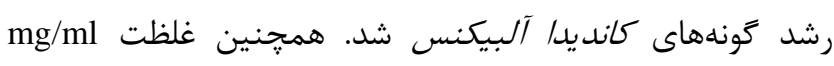

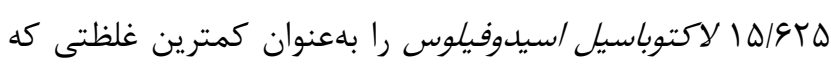

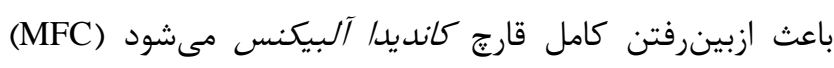

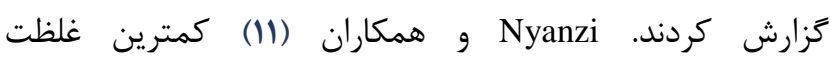

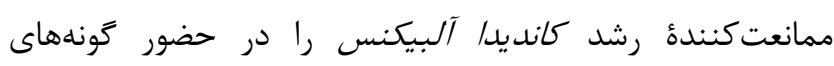
لاكتوباسيلى بررسى و كزارش كردند كه مقدار

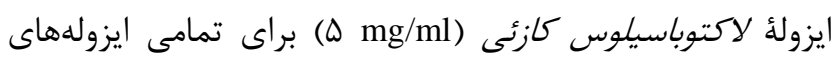

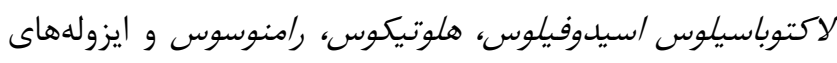

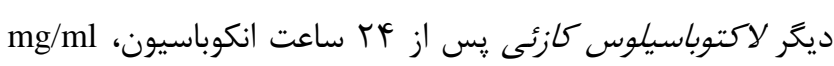

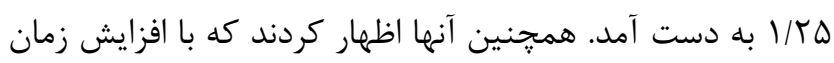

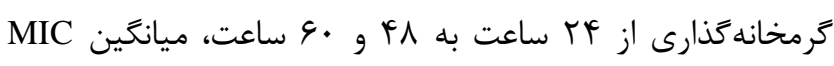

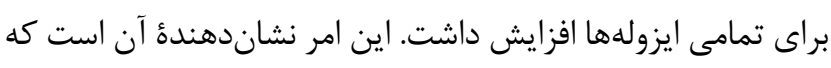

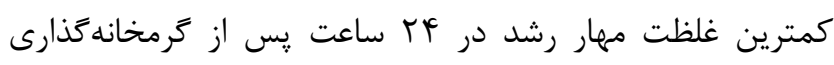

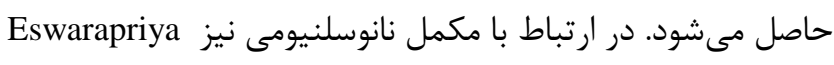

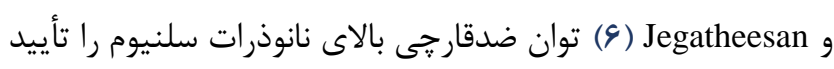
كرده و مقدار MIC نانوذرات سلنيوم را روى كانديدا آلبيكنس

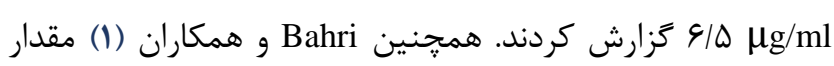

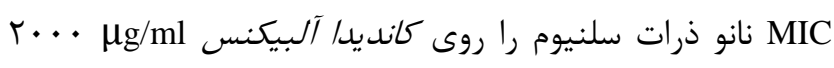

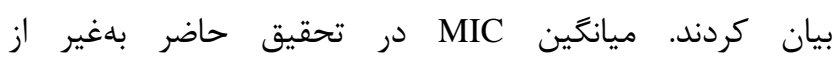

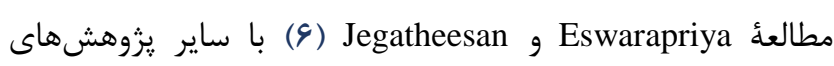
مشابه همخوانى نسبى داشت. با توجه به تفاوت هاى زياد بان براى مقادير

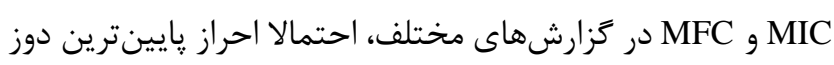

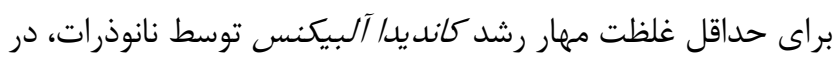

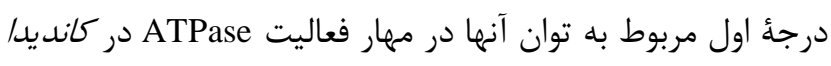

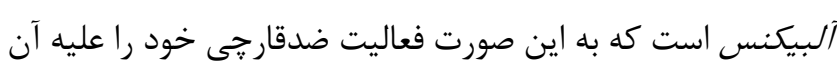

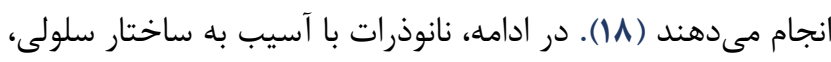

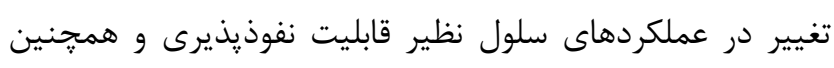

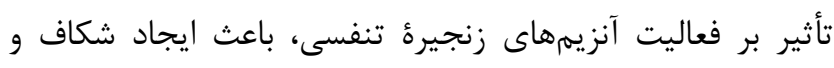

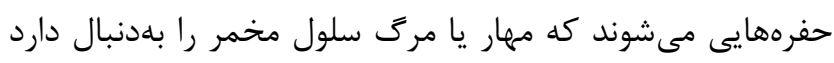




$$
\begin{aligned}
& \text { تعارض منافع } \\
& \text { بين نويسند كان تعارض در منافع تزارش نشده است. } \\
& \text { سياسَزْارى } \\
& \text { بدينوسيله از جناب آقاى دكتر پيمان زارع، آقاى دكتر } \\
& \text { اميرمحمد گو ₹انيان و خانم مهندس اردوخانى كه در انجام اين } \\
& \text { تحقيق زحمات زيادى متقبل شدند، تشكر و قدردانى مىشود. }
\end{aligned}
$$

\section{References}

1. Kazempour ZB, Yazdi MH, Rafii F, Shahverdi AR. Sub-inhibitory concentration of biogenic selenium nanoparticles lacks post antifungal effect for Aspergillus niger and Candida albicans and stimulates the growth of Aspergillus niger. Iranian Journal of Microbiology. 2013; 5(1): 81-5. PMID:23466957 PMCID:PMC3577562

2. Braide W, Anyanwu GO. The effects of Lactobacillus acidophilus (Probiotics) and other fungicidal agents against vagina Candida albicans. International Journal of Advanced Research in Biological Sciences. 2018; 5(4): 37-63.

3. Calomme MR, Vanden-Branden K, Vanden-Berghe DA. Selenium and Lactobacillus species. Journal of Applied Microbiology. 1995; 79(3): 331-40.

4. Cheraghi Saray S, Hosseinkhani A, Janmohammadi H, Zare P, Daghighkia H. Thermal and probiotic treatment effects on restaurant waste for incorporation into poultry diet. International Journal of Recycling of Organic Waste in Agriculture. 2014; 3(3): 1-7. https://doi.org/10.1007/s40093-014-0071-1

5. Clarke M, Davies DP, Odds F, Mitchell C. Neonatal systemic candidiasis treated with Miconazole. $\mathrm{Br}$ Med J. $\quad$ 1980; 281(6236): 354-64. https://doi.org/10.1136/bmj.281.6236.354

6. Eswarapriya B, Jegatheesan KS. Antifungal Activity of Biogenic Selenium Nanoparticles Synthesized from Electronic Waste. International Journal of PharmTech Research . 2015; 8(3): 383-6.

7. Hongfei Y, Gongjian F, Zhenxin G. Optimization of culture parameters of selenium-enriched yeast (Saccharomyces cerevisiae) by response surface methodology (RSM). LWT-Food Sci Technol. 2010; 43(4): 666-9. https://doi.org/10.1016/j.lwt.2009.11.010

8. Huh AJ, Kwon YJ. "Nanoantibiotics": a new paradigm for treating infectious diseases using nanomaterials in the antibiotics resistant era. Journal of Controlled Release. 2011 ; $156(2)$ : $128-45$. https://doi.org/10.1016/j.jconrel.2011.07.002
9. Krittaphol W, Wescombe PA, Thomson CD, McDowell A, Tagg JR, Fawcett JP. Metabolism of LSelenomethionine and Selenite by Probiotic Bacteria: In Vitro and In Vivo Studies. Biol Trace Elem Res. 2011; 144(1-3): 1358-69. https://doi.org/10.1007/s12011-0119057-2

10. Magnusson J, Strom K, Roos S, Sjogren J, Schnürer J. Broad and complex antifungal activity among environmental isolates of lactic acid bacteria. FEMS Microbiol Lett. 2003; 219(1): 129-35. https://doi.org/10.1016/S0378-1097(02)01207-7

11. Nyanzi R, Awouafack MD, Steenkamp P, Jooste PJ, Eloff JN. Anticandidal activity of cell extracts from 13 probiotic Lactobacillus strains and characterisation of lactic acid and a novel fatty acid derivative from one strain. Food Chemistry. 2014; 164(1): 470-5. https://doi.org/10.1016/j.foodchem.2014.05.067

12. Otang WM, Grierson DS, Ndip RN. Antifungal activity of Arctotis arctotoides (L.f.) O. Hoffm and Gasteria bicolor Haw against opportunistic fungi associated with human immunodeficiency virus/acquired immunodeficiency syndrome. Pharmacogn Mag. 2012; 8(30): 135-40. https://doi.org/10.4103/0973-1296.96564

13. Pfaller MA, Houston A, Coffmann S. Application of CHROMagar Candida for rapid screening of clinical specimens for Candida albicans, Candida tropicalis, Candida krusei, and Candida (Torulopsis) glabrata. J Clin Microbiol. 1996; 34(1): 58-61.

14. Prentice AG, Warnock DW, Johnson SA, Phillips MJ, Oliver DA. Multiple dose pharmacokinetics of an oral solution of Itraconazole in autologous bone marrow transplant recipients. J Antimicrob Chemother. 1994; 34(2): 247-52. https://doi.org/10.1093/jac/34.2.247

15. Selvarangan R, Limaye AP, Cookson BT. Rapid Identification and Differentiation of Candida albicans and Candida dubliniensis by Capillary-Based Amplification and Fluorescent Probe Hybridization. J Clin Microbiol. 2002; 40(11): 4308-12. https://doi.org/10.1128/JCM.40.11.4308-4312.2002

16. Stabnikova O, Ivanov V, Larionova I, Stabnikov V, Bryszewska MA, Lewis J. Ukrainian dietary bakery product with selenium-enriched yeast. LWT- Food Science and Technology. 2008; 41(5): 890-5. https://doi.org/10.1016/j.lwt.2007.05.021 


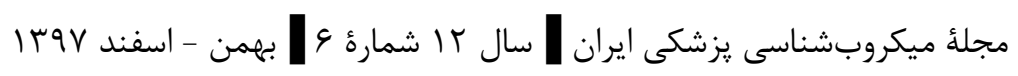

17. Strus M, Kucharska A, Kukla G, Wloch M, Marsez K, Heczko PB. The in vitro activity of vaginal Lactobacillus with probiotic properties against Candida. Infect Dis Obstet Gynecol. 2005; 13(2): 69-75. https://doi.org/10.1080/10647440400028136

18. Wani IA, Ahmad T, Manzoor N. Size and shape dependant antifungal activity of gold nanoparticles: a case study of Candida. Colloids Surf B Biointerfaces. 2013; 101(1): 162-70. https://doi.org/10.1016 j.colsurfb.2012.06.005
19. Zamre DK, Mishra B. Enhanced antimicrobial activity of probiotics through selenium nanoparticles enrichment against gastrointestinal pathogens. Int $\mathbf{J}$ Pharm Sci Res. 2018; 9(2): 738-42. https://doi.org/10.13040/IJPSR.0975-8232.9(2).738-42

20. Zawrah MF, Abd El-moez S. Antimicrobial activities of gold nanoparticles against major foodborne pathogens. Life Science Journal. 2011; 8(4): 37-44.

21. Zhang B, Zhou K, Zhang J, Chen Q, Liu G, Shang N, et al. Accumulation and species distribution of selenium in Se-enriched bacterial cells of the Bifidobacterium animalis 01. Food Chemistry. 2009; 115(2): 727-34. https://doi.org/10.1016/j.foodchem.2008.12.006 